\title{
Quantitive Ultrasound for Two Different Osteopenia Rat Models
}

\author{
Shigeyuki Kanai \\ Research Institute of Oriental Medicine \\ Kinki University School of Medicine \\ Department of Anatomy, \\ Kansai College of Acupuncture Medicine \\ Norimasa Taniguchi \\ Department of Science \\ PIP-FUJIMOTO Corporation
}

\begin{abstract}
Key words : Quantiative ultrasound (QUS), Bone mineral density (BMD), Ovariectomized rat (OV rat), Adjuvant arthritis rat (AA rat)
\end{abstract}

\section{Introduction}

Recently osteoporosis has become a topic of general interest. There are very few studies that give scientific data on osteoporosis ${ }^{11}$.

It was previously reported finding that dual-energy X-ray absorptiometry (DEX) and computed X-ray absorptiometry (CXD) have both been useful, using two different rat models, ovariectomized (OV) rat and adjuvant arthritis (AA) $\mathrm{rat}^{233)}$.

Moreover, in this paper, we describe the usefulness of QUS as well as CXD or DEX for osteoporosis diagnosis.

\section{Materials and methods}

\section{Animals}

Wistar rats and Sprague-Dawley (SD) rat, were obtained from Japan SLC, lnc (Hamamatsu Japan). The animals were given free access to solid rodent chow (CE-2: Nihon Clea, Osaka, Japan) and water. They were housed in a room with a $12 \mathrm{~h}$ light/dark cycle, at a temperature of $23.0 \pm 1.0^{\circ} \mathrm{C}$ and a relative humidity of $50 \pm 5 \%$. Rats were acclimated to the environment for one week before the experiment.

\section{Preparation of animal models for osteopenia}

In this experiment, 12 female Wistar rats (6 weeks old, 120-140g) and 12 female SD rats (6 weeks old, 120-140g) were used. Rats were divided into four groups (six rats/group) to carry out this experiment. Group one Wistar rats were OV and these OV rats were subsequently bred for subsequent 24 week to induce systemic osteoporosis. Group two Wistar rats were untreated and these normal rats were bred for 24 weeks as the control for group one. In group three SD rats, AA was induced by intradermal injection $(0.5 \mathrm{mg} / \mathrm{rat})$ of heat-killed Mycobacterium butyricum 
(Wako Pure Chemical Industries, Ltd., Osaka, Japan) suspended in paraffin oil (Wako Pure Chemical Industries, Ltd., Osaka, Japan), into the base of left hind leg. After injection, these AA rats were bred for 24 weeks to induce extensive bone resorption in distal diaphysis of the tibia. Group four SD rats were untreated and these normal rats were bred for 24 weeks as the control for group two.

\section{Measurement of bone mineral density}

Measurement of bone mineral density (BMD) was performed on all 30-week-old rats. After being deeply anesthetized with ether, the animals were sacrificed. The left tibia was isolated from each animal and its BMD was measured by $\mathrm{QUS}^{6}$.

QUS was analyzed into two direction, vertical bone matrixs (affected by loads) or horizontal bone matrixs (not affected by loads), using AOU-100 (Aloca Co., LTD., Tokyo, Japan)

\section{Statistical Analysis}

All values were expressed as means \pm SE. Difference analysis on each value between each group was performed using Wilcoxon signed rank test for paired comparisons. Probability levels less than 0.05 were considered significant differences.

\section{Results}

a) On QUS mean horizontal BMDs of the tibiae were decreased about $62 \%$ in OV rats or $14 \%$ in AA rats compared to those of the respective controls (Fig. 1).

b) On QUS mean vertical BMDs of tibiae rats were decreased about $13 \%$ in VO rats or $44 \%$ in AA rats compared to those of the respective controls (Fig. 2).

BMDs of QUS in horizontal line showed significant positive correction between DEX and CXD (Fig. 3).

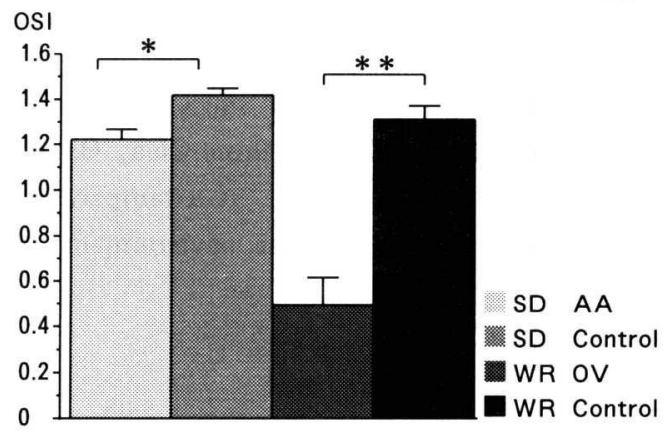

Fig. 1 BMDs for osteopenia by QUS (in horizontal) in OV rats and AA rats. All values were expressed as means $\pm \mathrm{SD}$. ${ }^{*} \mathrm{p}<0.05 ;{ }^{* *} \mathrm{p}<0.01$; significantly different between each group.

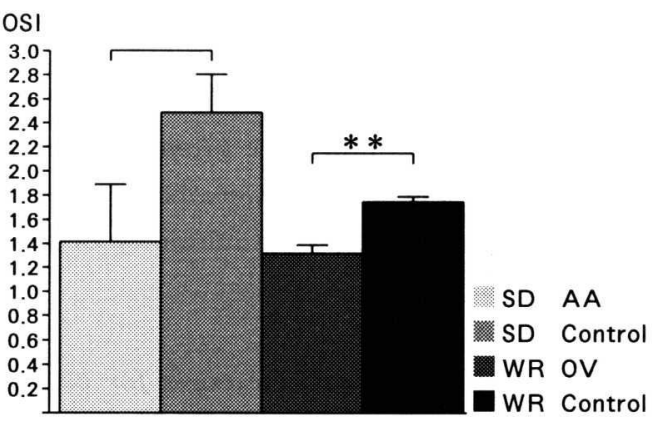

Fig. 2 BMDs for osteopenia by QUS (in vertical) in $\mathrm{OV}$ rats and $\mathrm{AA}$ rats. All values were expressed as means $\pm \mathrm{SD}$. ${ }^{* *} \mathrm{p}<0.01$; significantly different between each group. 


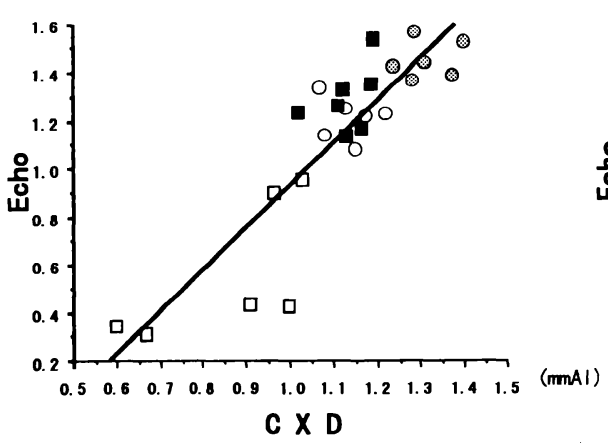

$y=0.02 x-1.875$

$r=0.787$

p<0. 001

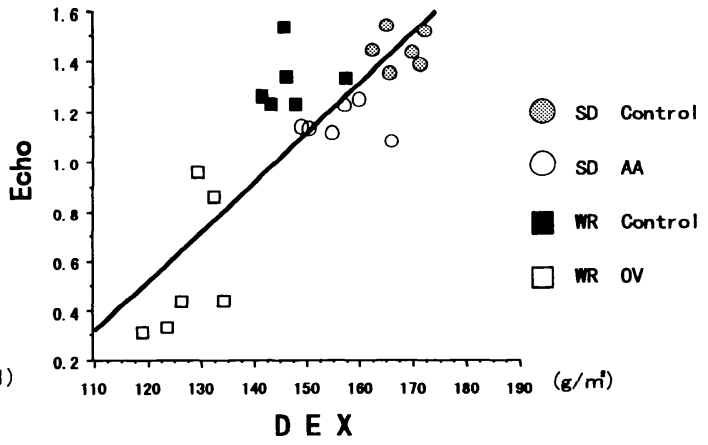

$y=1.764 X-0.831$

$r=0.852$

$p<0.001$

Fig. 3 Correlation between BMDs for osteopenia by QUS (in horizontal) in OV rats and rats AA.

\section{Discussion}

QUS has been developed in recent years for the assessment of skeletal status in osteoporosis ${ }^{7)}$. However, we observed that longterm immobility via severe osteoarthritis induced osteopenia in chronic AA rats up to 6 months post-OV as an experimental model of $\mathrm{RA}$. In these chronic AA rats, significant reduction of BMD was detected by QUS.

It is reported that QUS provides offere information related to bone structure as well as $\mathrm{BMD}^{5}$. Especially, in cases of osteoporosis, many papers reports that BMDs decreased in horizontal bone matrixs from an early stage, while BMDs in vertical bone matrixs are ultimately maintained $^{6}$.

For this reason, we assent that the reduction of mean BMDs of tibiae in horizontal bone matrixs in OV rats or AA compared with those of the controls, was caused by osteoporosis.

One issue to be noted at this stage is that QUS examination is more prevalent than QCT, mainly due to availability, usability and low exposure dose ${ }^{7)}$. Our results demonstrate that QUS analytical methods are a safe and easily applicable measurement and may provide sufficiently reliable and suitable tools for assessing BMD in osteopenia.

The low cost and good portability make QUS an attractive technology for assessing the risk of fractures in large population. Additional clinical applications of QUS, especially the assessment of the rate of change for monitoring disease progression or response to treatment, require further investigation.

\section{Conclusions}

In summary, QUS was a reliable and suitable tool for assessing BMD for osteoporosis.

\section{Acnowledgment}

At the end, we would like to express his sincere gratitude to prof.Kimura, who provided 
released data.

The study was mainly carried out at the Research Institute of Oriental Medicine, Japan.

\title{
References
}

1) Kanai, S. et al.: Computed X-ray absorptiometry for two different osteopenia rat models. J Kansai College of Acupuncture Medicine, $14: 83-86,1998$.

2) Kanai, S. et al.: The effect of Kami-kihi-to on the maintenance of bone mass in patients with osteoporosis. $\mathrm{J} J$ Orient Med., 49(1) : 59-66, 1998.

3) Kanai, S. et al.: Comparison of measuring Methods for Osteopenia Using Two Different Rat. Orthopedic \& Traumatology, 48(4): 1237-1241, 1999.

4) Nicholson P.H.F. et al.: The dependence of ultrasonic properties on orientation in human vertebral bone. Phys Med Biol, 39 : 1013-1024, 1998.

5) Miller, C. G., et al.: Ultrasound velocity measurements through the calcaneous which velocity should be measured. Osteoporosos Int. $3: 31-35,1998$.

6) Turner C. H., et al.: Ultrasonic velocity as predictor of strength in bovine cancellous bone. Calcif Tissue Int., 49 : 116-119, 1991.

7) Wakamathu, H. et al.: Quantitative X-ray computed Tomography. J J Clinic Med., 56(6) : 1998.

〈和文抄録〉

\section{実験的骨減少症ラットに対する超音波測定法の検討}

\author{
近畿大学東洋医学研究所, 関西鋮炎短期大学 \\ 金 井 成 行 \\ ピップフジモト株式会社開発研究部 \\ 谷口典 正
}

実験的骨減少症モデルと考えられている卵巣摘出 (OV) ラットと実験的関節症モデルであるアジュバ ント関節炎 $(\mathrm{AA})$ ラットの脛骨の骨塩量を超音波測 定法にて検討を行ったＯV ラット，AA ラットの脛 骨の加重に影響を受けない（水平方向）の骨塩量は, 超音波法において有意にコントロール群に比べて減少
を示したが，荷重に影響を受ける（垂直方向）骨塩量 では OVラットのみ有意な減少を示した。

また，超音波法において減少を示した水平方向の脛 骨の骨塩量は DEX 法 CXD 法とも有意に相関が認め られた。これらの結果から超音波法も骨減少の評価に 充分有用であることが示唆された。 